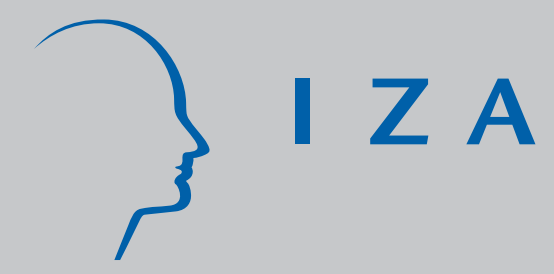

IZA DP No. 1779

Labor Supply and Child Care Costs: The Effect of Rationing

Daniela Del Boca

Daniela Vuri

September 2005 


\title{
Labor Supply and Child Care Costs: The Effect of Rationing
}

\author{
Daniela Del Boca \\ University of Turin, CHILD \\ and IZA Bonn
}

Daniela Vuri

University of Florence, CHILD

and IZA Bonn

Discussion Paper No. 1779

September 2005

\author{
IZA \\ P.O. Box 7240 \\ 53072 Bonn \\ Germany \\ Phone: +49-228-3894-0 \\ Fax: +49-228-3894-180 \\ Email: iza@iza.org
}

\begin{abstract}
Any opinions expressed here are those of the author(s) and not those of the institute. Research disseminated by IZA may include views on policy, but the institute itself takes no institutional policy positions.

The Institute for the Study of Labor (IZA) in Bonn is a local and virtual international research center and a place of communication between science, politics and business. IZA is an independent nonprofit company supported by Deutsche Post World Net. The center is associated with the University of Bonn and offers a stimulating research environment through its research networks, research support, and visitors and doctoral programs. IZA engages in (i) original and internationally competitive research in all fields of labor economics, (ii) development of policy concepts, and (iii) dissemination of research results and concepts to the interested public.
\end{abstract}

IZA Discussion Papers often represent preliminary work and are circulated to encourage discussion. Citation of such a paper should account for its provisional character. A revised version may be available directly from the author. 


\section{ABSTRACT}

\section{Labor Supply and Child Care Costs: The Effect of Rationing*}

In Italy the participation of women has not increased very much in the last few decades relative to other developed countries and it is still among the lowest in Europe. The female employment rate stands almost 13 percentage points below the EU average and 22 below the Lisbon target. One of the most important reasons is related to the characteristics of child care system. In this paper we analyze the characteristics of the child care system in Italy and its relationship to the labor market participation decision of mothers. We present a simple discrete choice framework in which the two decisions can be jointly considered, which also allows for simple forms of rationing and estimate a bivariate probit model of the child care and employment decisions and interpret the results within the framework of our model. We find evidence that rationing is an important factor in interpreting price effects on utilization rates.

JEL Classification: J2, C3, D1

Keywords: $\quad$ labor market decisions, fertility, child care

Corresponding author:

Daniela Del Boca

Department of Economics

New York University

269 Mercer Street

New York City, NY 10003

USA

Email: dd12@nyu.edu

\footnotetext{
* This research was partially supported by grants from EC Grant "The Rationale of Motherhood", the Compagnia di San Paolo and the Italian Ministry of Universities and Scientific Research. We would like to thank Christopher Flinn, Robert Moffit, Siv Gustafsson and Alexander Voicu for helpful comments as well as seminar participants at Johns Hopkins University, Amsterdam, the University of Florence and IZA (Bonn).
} 


\section{Introduction}

One of the most significant long term trends in the labor market in most OECD countries has been the increase in the proportion of working mothers. This is due both to the fact that a growing proportion of households with both parents present have become dual earner families, and as a result in the increase in the employment rate in the population of lone parent households. As a consequence of these changes parents have come to increasingly rely upon individuals and institutions outside of the immediate household for assistance in the child-rearing task. Because of this, the relationship between institutionalized child-care and child outcomes and the availability and affordability of child care and labor market participation decisions has been receiving increasing attention among researchers and policy-makers. As entering the labour market is strongly related with the participation in the child care market, we expect women's entry decision to depend partly on the cost of child care.

The increase in the incidence of non-parental child care has been object of study since the mid-1970s in the United States, United Kingdom, and Northern Europe, though not in Italy where it only recently has begun to receive attention. One reason is related to Italian employment trends. In Italy a much smaller proportion of married women are formally employed relative to the proportions observed in most other European countries (Boeri, Del Boca and Pissarides 2005)

A second reason is the serious data limitations that Italian researchers face. The ISTAT Multiscopo survey contains a great deal of information regarding the household's use of child care but does not provide data on family income, wages, etc. The ECHP (European Community Household Panel), which has the advantage of being comparable with that collected in several other European countries, contains only a very limited amount of information on child care. The Bank of Italy Survey of Household Income and Wealth (SHIW), which is the most complete micro-survey on the income and wealth of Italian households, does not collect information on child care on a regular basis. In order to overcome these limits, we combine two datasets (ISTAT Multiscopo and SHIW 1998), by imputing the income variables of individuals taken from the SHIW to identical individuals from the Multiscopo survey using a statistical matching method (Del Boca, Locatelli, Vuri 2005).

The objective of the analysis in this paper, which is both descriptive and 
analytic, is to study the effect of child care cost on labor market participation decisions. From a theoretical point of view, the impact of child care costs on labour supply is well determined: since child care costs increase the mother's reservation wage, high child care costs may lead to a lower labor force participation of women with children, especially if young. This result has been found in a large number of empirical studies for the US, the UK and Canada. However, what makes this task particularly difficult is the fact that child care is a good with several characteristics (e.g., quality, availability, cost, convenience). We will ignore the variability in this good along most of these dimensions, and instead choose to focus on the choice between formal child care and no use of child care and employment decisions. In particular, this paper explicitly considers the role child care costs play in the decision of women with young children to participate in the labor market and to purchase child care services.

While each type of child care is characterized by a price to a particular household, ${ }^{1}$ it is also characterized by hours of availability and other factors related to accessibility. This differentiation is likely to be especially great in Italy. For example, in Southern areas of the country the number of places in public child care is extremely limited.

We analyze how the costs of child care, in addition to the problem of gaining access to a public sector slot, distorts the labor market decision of mothers of young children. In the presence of rationing, while the published price of public child care may be relatively low in comparison to the price of private child care, its effective price is infinite to those families that cannot gain access to the system.

Our main focus will be on the "mismatch" between the characteristics of the Italian child care system and the demands of formal employment in the Italian labor market. While Italian public sector child care offers very limited hours of operation, consist with what might be attractive to nonworking mothers or those employed at flexible, part-time jobs, such jobs are not to be found in the formal sector of the economy. Concerning private market child care, even if all the children can gain access to it, private services are even less widespread than the public ones and their costs are relatively much higher. Therefore they cannot be considered as substitute in the child care

\footnotetext{
${ }^{1}$ These prices may vary, especially in the public sector, by demographic characteristics and the financial resources of the household.
} 
market (Del Boca Locatelli and Vuri 2005).

The plan of the paper is as follows. In Section 2 we provide a brief overview of previous research on this subject. In Section 3 we consider how preferences and rationing constraints jointly determine observed household choices, which is particularly relevant in the child care choice context. Section 4 contains a description of the child care system as it currently exists in Italy. This knowledge will be important for understanding the motivation behind the behavioral model developed in Section 5. In Section 6 we discuss the data used in our (preliminary) empirical analysis, and Section 7 contains a discussion of results. Section 8 offers a provisional conclusion.

\section{Previous Research}

A number of researchers have attempted to estimate the behavioral effects of changes in income, wage rates, and the price of child care on various family decisions. Research on the relationship between child care and labor market participation in the U.S and the U.K. has mainly focused on the effect of child care costs on employment decisions (Heckman 1974, Blau and Robins 1988, Connelly 1992, Ribar 1995, Averett et al 1997, Powell 1997, Viitanen 2004, among others). These studies have used a variety of methodologies to estimate these impacts taking into account the potential endogeneity of observed costs due to the heterogeneity in this good (particularly along the quality dimension).

In one of the first examinations of this topic, Heckman (1974) estimates a child care price function which incorporates measures of the availability of child care and its costs; he pursues this strategy because he does not have cost data directly available. Blau and Robins (1988) include a regional average of day care expenditure as a proxy for price, but did not control for household-specific information such as the age of the youngest child. Connelly (1992) uses predicted expenditures as an instrument for child care costs in an accompanying labor force participation equation; the cost instrument controlled for regional variation and family characteristics. Ribar (1992), using a more structural approach, considers expenditures per hour of care per child as a measure of child care costs.

Generally these studies have found that family behavior is significantly influenced by child care policies. Blau and Robins (1988) estimate child care 
price elasticities for married women of -.38 with respect to labor supply and -.34 with respect to the demand of formal child care. These estimates implied that if the child care prices were zero, 87 percent of mothers would work in contrast with a value of 58.8 actually working. In performing this policy experiment, Blau and Robins compute the response at the characteristics of the average woman in the sample. In contrast, Connelly (1992) evaluate the impact of such a policy on the labor market decisions of each woman in the sample. She finds a less substantial labor supply effect: if universal no cost child care were available, the model predicts that 68.7 per cent of women would be employed. A similar result was obtained for the UK (Viitanen 2004). The results of all these studies show that child care costs are a very significant determinant of the demand for these services and employment decisions, which are of course very highly associated themselves, ranging from -0.02 (Ribar 1995) to a low of -0.82 (Averett et al 1997). ${ }^{2}$

Other studies focusing on other countries find quite different results. Cobb-Clark et al. (2000) find that child care costs in Australia are not an important barrier to labor market participation, but affect significantly the choice of child care. A quite different picture emerges from empirical research using data from Northern European countries. Gustaffson and Stafford (1992) investigate the responsiveness of the decision of women to work and use public child care in response to variation in child care fees, availability of places, and spouse's income in Sweden. ${ }^{3}$ They found that in regions in which child care places do not appear to be rationed, higher fees significantly lowered the probability of mothers' market work and public child care choice, while in areas where rationing is more severe there is little evidence of significant price effects. Kornstad and Thoresen (2003) examine the case of Norway and analyze a model to simulate the female labor supply effects of the Norwegian home care allowance reform taking into account rationing.

Studies analyzing Continental and Mediterranean Europe use a similar approach. Del Boca (1993) estimates a model similar to that of Blau and

\footnotetext{
${ }^{2}$ Some of these studies have also compared the employment responsiveness to child care costs for married mothers and single mothers. The results for single mothers are much less robust (Kimmel 1998, Jenkins and Symons 1995, among others).

${ }^{3}$ Sweden is widely held to have the highest quality child care among the countries of the region, and also offers the greatest degree of availability. The participation rate of Swedish mothers is also the highest in the region.
} 
Robins (1988) to determine the effect of child care costs on the participation decisions of married women allowing for the choice between part-time and full-time work and between public and private child care systems. The estimation of the relationship between child care costs and labor supply shows that a reduction in child care costs increases the probability of mothers' parttime employment but has a less significant effect on the probability of working full time. These results raise some concerns given that part-time employment opportunities are in such a short supply in the Italian labor market. ${ }^{4}$ Using the Bank of Italy data, Chiuri (2000) does not find significant effect of child care costs.

Kreynfeld and Hank (2003) do not find a significant effect of child care costs on the participation decision of mothers in Germany, explaining this result with the peculiar child care situation in Germany, where opening hours of child care facilities are not long and flexible enough to meet the demands of working mothers. Availability appears to be more important than costs. Wrohlich (2004) compares west and east Germany and reports significant but very small effects of child care costs on mother's labor supply.

Table 1 reports and summarizes the signs and the significance of the coefficients associated with child care costs and availability on labor market participation. The varying estimates certainly reflect differences in important institutional characteristics of the countries. In countries like US, Canada, UK, Australia where the child care services are provided at private level, the focus is on the costs and quality of the services, while in countries where the provision is mostly public (Sweden, Norway, Germany, Italy) availability seems to be as important as costs.

In this paper we focus on Italy which shares with some other European countries the characteristics of the so-called "Southern model": the lowest level of social protection (especially social expenditures for families and children) and the strictest employment regulations, which together require the family to provide essential "social" services (Ferrera, 1996). Gornick, Meyers and Ross (1997) have used the Luxembourg Income Study to analyze the effect of various policies that support employment for mothers of young chil-

\footnotetext{
${ }^{4}$ Empirical studies employing cross-country data have found a high correlation between the proportion of part time jobs and the participation rates of women, in particular married women with children (Meulders and Plasman 1994). The low proportion of part-time workers seems mainly to be induced by characteristics of the demand side of the labor market.
} 
dren. While Italy is ranked quite high for policies for mothers with children between 3-6, it is ranked quite low for policies for mothers with children under three. Bradshaw et al (1997) rank several countries (using a index ranging from 1 to 17) for the income support provided to families with children. Italy is ranked 10.3, Spain 12.8 and Greece 14.3, while Denmark is ranked 7.0, France is ranked 3.7, and Sweden earns a 5.3.

Given the extremely low level of family benefits, the family still acts as the explicit partner of the execution of social policies. In such a system, the family is forced to act as a buffer providing monetary and time transfers to its members to shield them from some of the harmful byproducts of rigid labor markets and limited income maintenance schemes.

Recent analyses have defined the Southern Model as the "family care model" and have tried to discuss the implications (relative to other possible social welfare state constructions) for the welfare of women and children (Antonnen and Sipilla 1996). In general, empirical analyses have indicated that the family and social policies of the Mediterranean countries have contributed to the worsening position of women and children (Esping Andersen 1999). Interventions producing reductions in the costs of children should be a focus for reducing the burden on the family. Ferrera (1996) and Addabbo (2001) analyze the positive experience in family-welfare mix of Emilia Romagna where expanded child care with longer hours have contributed to encourage women to work. It is reasonable to assume that similar types of interventions in other regions of Italy, particularly the South, could have very positive impacts on labor supply.

\section{Labor Supply Decisions and Characteris- tics of Child Care Services}

The analysis of the impact of child care policy on labor supply necessitates consideration of at least two dimensions of services: availability and costs. ${ }^{5}$ In this section we will discuss some issues of measurement as well as the relationship between costs and availability. In terms of the monetary cost

\footnotetext{
${ }^{5}$ Of course child care quality is an exceedingly important dimension as well. We largely neglect it here due to the absence of any information on the characteristics of child care services used in the data.
} 
of "formal" child care, they are typically significant. Estimates place child care expenses at from 30 to 50 per cent of the earnings of employed mothers with one child under the age of three. The analysis of availability focuses on the family's ability to find "appropriate" child care given the going price of services. It has been found that the shortage of child care options in terms of schedules and location severely limits the use of these services.

An important component of child care costs and availability concerns the relationship between the distances of the family's residence, the workplaces of the parents, and the location of the facilities. In a sense, availability of child care slots can only be defined with respect to a set of "acceptable" child care facilities to the family, and distance is a prime factor in defining this choice set. Say that there are 40 child care facilities in a particular urban area. Given the monetary cost of each, the distance of each from the family's residence and employment locations, and the quality of each, the family may decide that there are 10 facilities the use of which would provide positive surplus. Over these 10 facilities the family would have an ordering in terms of preferences. Then we will say that the family is limited by "availability" if there is no vacancy for their child in any of the 10 "acceptable" facilities. While there may be vacancies in the 30 nonacceptable facilities, these will not be used.

Note that accessibility will impact the relationship we observe between price (and quality if we were looking at it explicitly) and the utilization of services even for those families who utilize formal child care. Returning to our example in the previous paragraph, say that among the 10 acceptable child care facilities the ranking the household assigns to them is a decreasing function of the price charged. If in this city accessibility is low, then it is relatively likely that one of the least favorite (but acceptable) facilities will be utilized, one with a relatively high price. However, if availability were guaranteed at all facilities, the one with the lowest price would have been observed. The point of this example is that availability will impact the characteristics of child care services chosen even when the household uses formal child care. In some real sense, the two aspects of choice are not independent and must be considered jointly. With better data it would be possible to do much more along this dimension than we are able to do here.

These considerations regarding child care availability suggest that the usual price effects (considering child care services as a normal good) should only be observed in areas in which availability constraints are not binding 
(see Gustaffson and Stafford 1992). In other areas, as our example suggests, the relationship between price and utilization will be much "noisier."

The issue of child care availability is especially important in countries with low birth rates. For example, in a country like Italy where the average number of children is close to 1 and a high proportion of children grow up without siblings, the purpose of child care is not only supervision and care but also represents an essential socialization opportunity. This is one reason why women who do not work still use child care in these countries.

Child care costs impact family decision making in two ways. First, child care costs can be thought of as a part of the cost of rearing a child and so affect decisions in which the cost of children is a relevant factor, most importantly fertility. In addition, given the presence of a child, child care costs lower the mother's effective wage in the labor market and thus impact decisions for which the mother's wage is a relevant "state variable."

The higher the cost of child care, the higher the cost of an additional child. This leads to the prediction that higher child care costs will tend to decrease fertility (Cigno 1991, Del Boca 2002, Ermisch 1989). In most families mothers are the members of the families with the lowest potential earnings and hence are the "marginal" workers in the formal labor market. Once the fertility decision has been made, the major impact of child care costs is on the wage of the working mother. Given that women are the principal caregivers in the household, the mother bases her decisions on the costs and benefits of working in the labor market and these will depend on her wage minus the cost per hour worked of child care. Increasing the cost of extra-family child care decreases her effective wage. A decrease in her effective wage decreases the probability of participation in the labor market. If she is still participating a decline in her effective wage has two offsetting effects on the number of hours she will work. A decrease in the wage lowers the amount of family income, which has the effect of increasing the number of hours she will work in the market. But the decrease in the wage lowers the value of an extra hour spent in the labor market relative to the value of an extra hour spent at home. So the number of hours of work should decrease as the cost of child care increases. The effect of child care costs will be larger on women's participation because they may not be able to adjust their hours in the labor market to exactly equal their preferred number of hours of work. 


\section{The Child Care System in Italy}

In Anglo-Saxon countries, where private provision and financing of child care prevails, the costs of child care are an important variable affecting the labor market participation decisions of women. In Italy (as well as in other countries predominately found in Europe), where there is a mixture of private and public-funded child care, the direct costs do not seem to be as significant of a determinant of usage and labor market participation of mothers. In the U.S. and U.K. there is a very diverse set of child care arrangements, in terms of type and costs, from which to choose. This diversity, which offers a wider range of choices to parents, creates difficulties for the study of price responsiveness because of product heterogeneity and unmeasured quality differences in this market. In Italy, as in other European countries (such as Sweden), formal child care is judged to be of high quality and quality levels are set by the federal government so that the problem of unmeasured quality differences in the child care market is of less concern. Finally while for market economies the problem of availability/accessibility is related to the ability/inability to pay the market price for the quality of child care parents want, in economies where public provision prevails the problem of availability is a result of inherent shortage of child care slots.

In Italy the price of public child care is very heterogenous across areas. The amount parents pay differs from one municipality to another because the structure of the subsidy and the number of spaces is set by the local government. Unlike private child care, the costs of public child care depend on family size, family income, and family composition. The cost of public child care is lower for larger families in all areas.

Important differences characterize public child care for children younger than 3 and for those 3 or older. First of all, the costs of child care for children less than 3 years of age are much higher on average than are the costs of child care for children 3 or older, both in public and private child care services and for either part-time or full-time services.

Other differences concern the availability of public care. While public child care for children 3 or older has an utilization rate of 95 percent, child care for children younger than 3 is used only by 6 per cent of the population of children (OECD Employment Outlook, 2001). Because of this we focus

mainly on child care for children less than 3 years of age, which is crucial if mothers of young children are to participate in the labor market. 
The child care system for younger children is rationed in two ways. On one hand, the number of places available in the public sector are extremely limited. Moreover, the hours of public child care availability are rigidly set and have a limit of 7 hours a day. The child care for children 3-5 is rationed only in terms of the number of hours available.

Given this characteristic of the public child care system, it is not possible to accommodate full-time work schedules of both parents with the exclusive use of public child care. ${ }^{6}$ This rigidity in hours of service has negatively affected the growth in labor market participation of mothers with young children. The rate of growth in this statistic has been much lower over the past few decades in Italy than in other developed market economies. This situation is similar to the German institutional characteristics, in particular the combination of limited availability of child care facilities and the low price of child care.

While the availability of child care for children three and older is very uniform across regions, this is not the case for children under three. There are marked differences across regions. The proportion of children less than three years of age in public child care is around 15-20 percent in some areas of the North and only 1-2 percent in most Southern areas (this ratio is the number of places available divided by the population 0-3 years of age, Fondazione degli Innocenti 2002). Not coincidently, in the Northern areas the labor market participation rate of mothers is greater than 60 percent while in the Southern regions it is less than 20 percent.

Different accessibility rates have created a situation of more severe rationing of public child care in some areas of the country, especially in the South of Italy. In these areas women find it difficult to find a job in the formal labor market and are unemployed or work in the underground economy. Child care for young children is therefore rationed in two ways: (1) in the number of places available (fifty per cent of children on average are not accepted in the public care); and (2) in the hours of care offered (from a maximum of 7 on average in public child care to around 9-10 in private child care).

Given the existence of these two types of rationing many methodological problems arise. In order to illustrate the impact of child care characteristics

\footnotetext{
${ }^{6}$ Full-time employment typically necessitates that the employee be away from the home for approximately 9 hours per day, ignoring commuting time.
} 
on women's labor market participation, in the next section we look at a simple model of the mother's decision to work and use child care.

\section{Formal and Informal Childcare and the Em- ployment Decision}

To keep things extremely simple, and because the vast majority of employed mothers work at full time jobs in Italy, we will examine only the choice to work full-time or not. We shall also simplify along the child care dimension as well, in that we will assume that formal child care is utilized "full-time" if it is used at all. Furthermore, we shall simply assume that informal services are used if a woman is employed and there is a difference between the number of hours of employment and the number of hours of formal child care provided. If informal child care is utilized when the woman is not employed we will miss that; in our framework, there could be a desire for such child care as a way to increase the amount of the mother's leisure time or because the mother values the socialization and instruction her child(ren) receive at the childcare facility.

In line with the preferences assumed above, let the household's utility be given by

$$
U\left(C, L, d_{C C}\right)=\alpha \ln L+(1-\alpha) \ln C+\xi d_{C C},
$$

where $d_{C C}=1$ if the child is enrolled in formal child care and $\xi$ is the valuation of this event, which may take any value on the real line. As above, consumption is given by

$$
C=Y+w(T-H)-M_{C C},
$$

where $M_{C C}$ denotes the monetary cost of childcare and $H$ denotes the "standard" hours of work associated with full time employment. We set $H=40$. Assuming that full time formal child care supplies $\tau=35$ hours of service, the monetary costs of childcare are given by

$$
M_{C C}=d_{C C} \pi_{F} \tau+d_{E}\left\{d_{C C} \pi_{I}(H-\tau)+\left(1-d_{C C}\right) \pi_{I} H\right\},
$$

where $\pi_{F}$ denotes the hourly cost of formal child care, $\pi_{I}$ denotes the hourly price in the informal sector, and $d_{E}$ is an indicator variable that takes the value 1 if the mother is employed. 
As we discussed above, an important limitation of the Italian child care system is the relatively small number of available slots. To take this into account in a crude way necessitates that we view the availability of formal child care as probabilistic. If we let $Z$ denote demographic characteristics of the household that are formal and informal determinants of the mother's probability of obtaining a childcare slot, then we denote the probability that formal child care is in the choice set of the mother by $\delta(Z)$.

We can now set up the discrete choice problem that the mother faces at a point in time. Let $X$ denote a set of exogenous characteristics that affect the mother's chances of obtaining a job offer, and let the probability of receiving an offer be given by $\theta(X)$. Begin by assuming that she has access to a full time job offer of $w$ and that the cost of "informal" care for the children is $\pi_{I}$. If she has access to child care (so $d_{A}=1$ ), then her choices and their associated values are as follows:

$$
\begin{aligned}
& \text { Work }\left(d_{E}\right) \quad \mathrm{CC}\left(d_{C C}\right) \quad \text { Value } \\
& 0 \quad 0 \quad \alpha \ln (T)+(1-\alpha) \ln (Y) \\
& 1 \quad 0 \quad \alpha \ln (T-H)+(1-\alpha) \ln \left(Y+\left(w-\pi_{I}\right) H\right) \\
& 0 \quad 1 \quad \alpha \ln (T)+(1-\alpha) \ln \left(Y-\pi_{F} \tau\right)+\xi \\
& 1 \quad 1 \quad \alpha \ln (T-H)+(1-\alpha) \ln \left(Y+w H-\pi_{F} \tau-\pi_{I}(H-\tau)\right)+\xi
\end{aligned}
$$

We can summarize the value of the various choices by the expressions $V\left(d_{E}, d_{C C} \mid w, Y, \pi_{I}, \xi\right)$, where the other arguments $\left(T, H, \tau, \pi_{F}\right)$ are supressed for simplicity and because they are assumed to be constant in the population. We let the distribution of wage offers to mothers with productivity characteristics $Q$ be denoted by $G(w \mid Q)$ with associated (conditional) density $g(w \mid Q)$.

Consider the case in which we observe the woman at a job and using formal child care services. In this case we know that $w>0$, that is, she received a positive wage offer, and $d_{A}=1$, that is, she was granted access to formal child care services. Given these conditions, we know that the 
probability that the household chooses $\left(d_{E}=1, d_{C C}=1\right)$ is given by

$$
\begin{gathered}
p\left(d_{E}=1, d_{C C}=1 \mid w, Y, \pi_{I}, \xi\right)= \\
P(V(1,1 \mid S)-V(1,0 \mid S)>0, V(1,1 \mid S)-V(0,1 \mid S)>0, V(1,1 \mid S)-V(0,0 \mid S)>0) \\
\times \theta(X) \times \delta(Z) \\
=P\left((1-\alpha)\left(\ln \left(Y+w H-\pi_{F} \tau-\pi_{I}(H-\tau)\right)-\ln \left(Y+\left(w-\pi_{I}\right) H\right)\right)+\xi>0,\right. \\
\alpha(\ln (T-H)-\ln (T))+(1-\alpha)\left(\ln \left(Y+w H-\pi_{F} \tau-\pi_{I}(H-\tau)\right)-\ln \left(Y-\pi_{F} \tau\right)\right)>0, \\
\left.\alpha(\ln (T-H)-\ln (T))+(1-\alpha)\left(\ln \left(Y+w H-\pi_{F} \tau-\pi_{I}(H-\tau)\right)-\ln (Y)\right)+\xi>0\right) \\
\times \theta(X) \times \delta(Z) .
\end{gathered}
$$

We note the following features of this expression. Assume that the parameter $\alpha$ is fixed in the population, but that $\pi_{I}, w$, and $\xi$ are random, with each taking values on the positive real line $(0, \infty)$. Then in terms of the difference $V\left(1,1 \mid w, Y, \pi_{I}, \xi\right)-V\left(1,0 \mid w, Y, \pi_{I}, \xi\right)$, there are always combinations of $\left(\pi_{I}, \xi\right)$ for which this difference is positive. In terms of the difference $V\left(1,1 \mid w, Y, \pi_{I}, \xi\right)-V\left(0,1 \mid w, Y, \pi_{I}, \xi\right)$, the term $\xi$ cancels since formal child care is received under either alternative. For a sufficiently high value of $w$ and high value of $\pi_{I}$ this expression can be positive. Finally, in terms of $V\left(1,1 \mid w, Y, \pi_{I}, \xi\right)-V\left(0,0 \mid w, Y, \pi_{I}, \xi\right)$, this difference can be positive given relatively large values of $w$, high values of $\xi$, and low values of $\pi_{I}$. Of course, the fact that any given difference can be positive for certain combinations of $\left(w, \xi, \pi_{I}\right)$ does not mean that there exists values of these random variables for which all inequalities are simultaneously satisfied. We will investigate this issue through the use of simulation methods below.

When we observe a household in which the mother is not employed and/or is not using formal child care services, we don't know whether this is due to the fact that all options are available to the household (i.e., both work and formal child care services) and the particular outcome observed yields the highest value in the choice set with four possibilities, or whether it is attributable to the choice set being "restricted." Consider the case in which the mother is employed but does not use formal child care. By the fact that she is employed, we know that a job was available to her. That she does not use formal child care is due to the fact that it is available to her but its use does not yield as high a value as does using informal care or the fact that 
she would use it if available but it is not. Then we write the probability

$$
\begin{gathered}
p\left(d_{E}=1, d_{C C}=0 \mid w, Y, \pi_{I}, \xi\right)= \\
P(V(1,0 \mid S)-V(1,1 \mid S)>0, V(1,0 \mid S)-V(0,1 \mid S)>0, V(1,0 \mid S)-V(0,0 \mid S)>0) \\
\quad \times \theta(X) \times \delta(Z) \\
+P(V(1,0 \mid S)-V(0,0 \mid S)>0) \times \theta(X) \times(1-\delta(Z))
\end{gathered}
$$

where the second and third lines of the expression give the probability that the option $(1,0)$ is the best in the four element choice set multiplied by the probability that the household faced that choice set and the last line is the probability that $(1,0)$ was superior to $(0,0)$ times the probability that the household faced the two element choice set containing $\{(1,0),(0,0)\}$.

The probability that the mother does not work but does utilize formal child care is expressed in a similar manner. In this case the mother has the option of formal child care clearly, but we do not know whether she had a job offer or not. The probability of this event is

$$
\begin{gathered}
p\left(d_{E}=0, d_{C C}=1 \mid w, Y, \pi_{I}, \xi\right)= \\
P(V(0,1 \mid S)-V(1,1 \mid S)>0, V(0,1 \mid S)-V(1,0 \mid S)>0, V(0,1 \mid S)-V(0,0 \mid S)>0) \\
\times \theta(X) \times \delta(Z) \\
+P(V(0,1 \mid S)-V(0,0 \mid S)>0) \times(1-\theta(X)) \times \delta(Z) .
\end{gathered}
$$

The situation in which the mother does not work and does not use formal child care, which is the most frequently observed of the four outcomes in the data, has the most complicated expression for its probability since it could have been selected from any of four distinct choice sets. The probability is

$$
\begin{gathered}
p\left(d_{E}=0, d_{C C}=0 \mid w, Y, \pi_{I}, \xi\right)= \\
P(V(0,0 \mid S)-V(1,1 \mid S)>0, V(0,0 \mid S)-V(1,0 \mid S)>0, V(0,0 \mid S)-V(0,1 \mid S)>0) \\
\times \theta(X) \times \delta(Z) \\
+P(V(0,0 \mid S)-V(0,1 \mid S)>0) \times(1-\theta(X)) \times \delta(Z) \\
+P(V(0,0 \mid S)-V(1,0 \mid S)>0) \times \theta(X) \times(1-\delta(Z)) \\
+(1-\theta(X)) \times(1-\delta(Z)),
\end{gathered}
$$

where the last line is the probability that no job or child care slot was availability - in this case, the outcome $(0,0)$ is the default. 
As promised above, we now provide some simulation evidence regarding the performance of this model. To keep things simple, we will assume that the probabilities of receiving a job offer, the probability of having access to child care, and the wage offer distributions are fixed in the population at the common values $\theta, \delta$, and $G$. We assume that $G$ is lognormally distributed with parameters such that the logarithm of the wage distribution has mean 1.5 and standard deviation .5 . We assume that the probability of having a child care slot available to a family, $\delta$, is .7 , and the probability of having access to a job, $\theta$, is .6. The preference weight given to the woman's time in the household, $\alpha$, is set at .4. The woman is assumed to have a weekly time endowment of $T=90$, and other family income is set at $Y=500$. If the woman accepts employment, she must supply exactly $H=40$ hours at the job, and if her child participates in formal child care they spend $\tau=35$ hours a week in the program. If the mother is employed and the child participates in formal child care, it is assumed that the child is in formal child care while the mother is working.

The other random variables in the model in addition to the wage offer (if there is one) are the costs of informal child care, $\pi_{I}$, and the valuation of having the child participate in a formal child care program, $\xi$. We assume that both are lognormally distributed in the population. The $\ln$ of $\pi_{I}$ has mean -.3 and standard deviation 1 . The $\ln$ of $\xi$ has mean -2 and standard deviation 1.

We simulated choice probabilities by drawing 200 pseudo random draws for each of the random variables $\left(w, \pi_{I}, \xi\right)$. Using each of the 8 million combinations of these draws we first computed the optimal choice assuming that jobs and child care slots were available in all cases - that is, the full choice set of four options was present. We then drew other pseudo random variables for each case to determine the individual's "actual" choice set for this combination of the draws of $\left(w, \pi_{I}, \xi\right)$. Given the outcomes of these draws we redefined the choice set and determined the best choice within it. We then computed population averages of choices in the restricted and the unrestricted regimes.

The proportions appear in Table 2. We look first at the case without rationing. We see that the probability that a family with these characteristics would be using formal child care and have the mother at work is .45. The probability that the mother would be employed but the child would not be in formal child care is .07 , so that the overall employment probability is about 
.52 , with more than 80 percent of working mothers using formal child care. The probability of using formal child care and not working is .18, so that the proportion of families using formal child that have the mother employed is .72. The proportion of families in which the mother neither works nor has a job is .29.

The situation changes dramatically when rationing is added. The most severely impacted choice is that involving both being employed and using formal child care, since that is subject to rationing in both the labor market and the formal child care sector (which for simplicity we have assumed operate independently). The probability of having both choices available is only $.42(.6 \times .7)$. Accordingly, we see that the probability of working and using child care is reduced from .45 to .19 .

The "double rationing" has especially interesting implications for the choices $(1,0)$ and $(0,1)$. For example, for some combinations of the draws $\left(w, \pi_{I}, \xi\right)$ the preferred choice of the household would be $(1,0)$ when all choices were available. When a job is not available, however, this choice is not available and the household must make another. This lowers the likelihood of observing $(1,0)$. However, under rationing in some cases the preferred choice would have been something other than $(1,0)$ - like $(1,1)$ say - would be induced to choose $(1,0)$ in their restricted choice set. Thus rationing can only reduce the probability of observing $(1,1)$, can only increase the probability of observing $(0,0)$, but the net effects on the likelihood of observing the "mixed" cases $(1,0)$ or $(0,1)$ would seem to be ambiguous. In the example here we see that both have increased, with the probability that the household would have the woman working and the child not in formal child care changing from .073 to .095. The probability of observing child care but not employment also increases from .183 to .216.

The purpose of this section has been to outline a model that is capable of providing a link between formal child care and employment decisions. The model could be used to carry out policy simulations through manipulation of some of the parameters, especially the rationing probabilities $\delta$ and $\theta$. We intend to pursue the estimation of this model in the future, but for now we simply use it to motivate the more descriptive empirical analysis performed in the following section that investigates the link between these two choices. 


\section{Methods and Data}

The data used in this section combine information from Italian datasets, the SHIW and the Multiscopo survey, the first containing information on income and earnings and the second containing information on child care use, costs, hours of service and type of child care, i.e. formal (public and private) and informal. In order to merge these two datasets, we employ a statistical matching method which consists in imputing income and earnings variables of an individual from the SHIW to an identical individual from the Multiscopo (see Appendix 1 for the details on the matching procedure).

To be included in the sample used for estimation, households have to contain married adults with the youngest child under three years of age. Only 7 per cent of married couples in have the youngest child in this age range. This small percentage is a result of the low fertility rate in Italy (see Del Boca (2002) for an econometric analysis of the fertility decision in the Italian context). The geographic distribution of our final sample has 33.9 percent of households from the South, 12.8 from the Islands, 16.9 percent from the Central section, 19.3 percent from the Northwest, and 17.0 percent from the Northeast. In terms of labor market participation rates of the wives and mothers, 44.1 percent of the sample works (almost twice the the national figure).

Regarding child care utilization, we note that both formal child care (which includes public and private child care provided by schools) and informal child care (provided by relatives or friends or baby-sitter) are reported. However, the Multiscopo survey does not give information neither on the costs of the informal child care nor on the number of hours used, therefore we focus on the use of public and private services. Among families with children less than three years of age, 20.5 percent of households use child care. Of the working mothers, around 28 percent use formal child care, while only 14 percent of the not working mothers use formal child care.

The data on child care usage patterns of mothers by employment status indicate that there is a nonnegligible number of women who do not work but use child care. There is greater use of informal child care by women working full-time than by women working part-time. This could be due to the fact than women working full time need additional time relative to the formal child care hours.

The fact that the use of public and private child care is relatively low (in 
comparison to U.S. figures, for example) indicates the potential impact of the constraints presented by the high degree of rationing in access to public child care and the limited supply of both public and private child care slots. While the situation regarding private child care has changed somewhat during the intervening ten years, it remains true that there is an underprovision of formal child care services in general. Column 2 of Table A.1 shows the proportion of applications to child care which were accepted. It shows that the "rationing" concerns about $1 / 4-1 / 3$ of children: the proportion is higher in the southern regions where child care availability is lower.

We use a bivariate probit model to jointly estimate the probability of working and using child care. Given previous results (Heckman 1993) that have shown a very low responsiveness of hours of work to all measured variables (given the prevalence of full time jobs in the labor market), we use participation instead of hours. The dependent variables are whether the wife is working at the time of the interview and whether or not and the household uses formal child care.

Descriptive statistics for the variables used in the estimation are reported in Table 3. The variables utilized in the analysis include:

Personal Characteristics: parents' age and schooling, family non labor income and husband labor income.

Family Support: even if we have information on informal child care use from relatives and friends, we prefer not to use it directly in the estimation since it is potentially endogenous. We also use a variable indicating whether the family has received tranfers from relatives during the year of the interview as a proxy for family financial support.

Child Care System: As an indicator of the characteristics of the child care system, we use the percentage of available slots of public and private child care across region (given 100 the total in Italy). To test for the relevance of the rationing in child care we use as a proxy a dummy variable (NW) indicating that the household is situated in one of the region in which the provision of child care (both public and private) is greatest (Emilia Romagna, Lombardia and Veneto, see Table A.1).

Child care costs: the costs paid by households using school child care (either public or private).

Labor Market: As an indicator of the probability of locating a part-time job, we use the ratio of the number of part-time jobs to total employment in the region (see Table A.1), and as an indicator of availability of job in the 
region, we use the regional unemployment rate (Istat, Annuario Statistico Italiano 1999-2000).

If we look at Table 4, where the proportions of work and use of formal child care according to the presence of rationing $(\mathrm{NW}=1)$ in the area are reported, we notice that in absence of rationing most of the women are not using child care opportunities even if they are working. However the situation changes when rationing is added. The proportion of working women decreases sharply, while it increases the proportion of mothers who neither works nor use formal child care (from 0.31 to 0.51 ).

\section{$7 \quad$ Empirical Results}

As discussed in the description of the child care system in Italy and given the model we have constructed, we can expect that the price of child care may not "significantly" influence its use since for many regions there is a severe rationing of spaces. Only for less rationed areas would a clear impact be expected. Conditional on other household characteristics, we will assess whether the costs of child care have a larger (negative) effect on its utilizations in regions where rationing of spaces is less severe.

One important problem that we face in estimation is the issue of the endogeneity of child care costs. Since we would like to consider the two equations as constituting a (partial) demand system for the household, naturally we would like to include the parameters that characterize the household choice set. These include the prices of child care, both public and private, as well as any limitations on the uses of these services by a specific household. Since we only have child care costs paid by the household, this is not primarily a measure of the price but instead measures of utilization. To get around this endogeneity problem, we estimate the hourly child care costs equation from which to predict the child care costs potentially paid by all the households in the sample. The child care price regression is estimated using the appropriate correction for Heckman selection (see Heckman 1979). The results from the child care price equation, corrected for sample selection, are used to construct a predicted price of care for each mother in the sample. ${ }^{7}$ In this

\footnotetext{
${ }^{7}$ Most studies using US or Uk data employ a double selection model, since in many datasets childcare expenditures is observed only for working mothers who report paying for childcare. Therefore the selection arises from two sources: the decision to participate
} 
context, the child care cost equation can be estimated by OLS since all the families who use formal child care face some costs. ${ }^{8}$

Let the child care cost equation be:

$$
\pi_{F}=\alpha^{\prime} D+\nu_{F}
$$

where $\pi_{F}$ is observed only for those families using market child care, D is a vector of observed determinants and $\nu_{F}$ represents unobserved variation.

It is assumed that the costs of child care will vary according to some family characteristics. Expenditures on child care are expected to be higher for those families with higher levels of unearned income (or receiving tranfers from their parents) reflecting variations in the quality of care. The presence of alternative caregivers in the household, as represented by having parents still alive, is expected to affect the availability of low-cost care and hence expenditures. Wife's and husband's years of schooling are expected to affect positively child care expenditures, since more schooling is often associated with higher labor earnings. ${ }^{9}$ Finally, we use regional dummies which should capture differences in regulation and prices across regions. In order to identify the child care cost equation we use the ratio of the number of child care places available (for children under 3 years of age) to the number of children 3 years of age or less by area of residence in 1998. From the estimation of the child care equation, it turns out that regions in the South of Italy and Islands have lower child care costs, while in the North East (which is the wealthiest part of Italy) child care costs tend to be higher with respect to the Centre and North West. Families with higher levels of unearned income pay significantly more for care, as expected. The presence of alternative caregivers, in particular grandparents decreases child care costs while parental schooling increases child care costs (but these effects are not significantly different from zero). The selection term of the child care price equation, which accounts for the possibility that those mothers who work and choose formal child care

in the labor market and the decision of using paid care. However, in Italy, the link between the utilization of child care and employment is not very strong and therefore we employ a single sample selection correction term, as in Ribar (1992) and Wrohlich (2004).

${ }^{8}$ Wrohlich (2004) estimates the child care equation with a Tobit model since in her sample $10 \%$ of households using formal child care do not have to pay for it, i.e. face zero costs and this couls lead to negative predictions if using OLS.

${ }^{9}$ Household labor income is usually one of the criteria which determines the household child care expenditures. 
may face lower prices than the population as a whole, is negative but not significant. It means that the "amount" one pays for child care among those who do pay is not significantly affected by selectivity into the set of child care payers. ${ }^{10}$

Table 5 presents the estimates from a specification in which child care costs (as a proxy for price) enter the labor market participation and the child care equations alone. We consider the effect of child care and the effect of availability of child care conditional on several characteristcs of the environment (the proportion of part time work, the level of unemployment, the proportion of female employment in the public sector) and household characteristics. The results show that the price of formal child care does not have a significant impact on either choices. Households living in one of the three selected regions (i.e., $\mathrm{NW}=1$ ) have a higher probability of working and using child care, but both effects turn out to be not significant.

In terms of personal characteristics, we see that more highly educated women are more likely to work. Presumably, the main impact of higher education is on the market wage offer, so this finding is consistent with a wage effect. Instead, a husband with higher education discourages the wife participation to the labor market. Furthermore, highly educated parents are more likely to use formal child care. This result is also consistent with the fact that more highly-educated parents place greater value on the services provided by regulated child care settings (the opportunity for socialization with other children, relationship with teachers, etc.). Older mothers of young children are more likely to work probably because they invest more in human capital accumulation and have longer tenure if working. Higher household non labor income and husband labor income are associated with an increased utilization of child care, possibly arising from a higher level of demand for leisure, free of child care burdens by mothers from wealthier households (however the coefficients are not statistically significant even if of the expected signs).

Households in which the wife has at least one living parent have a higher probability of work and a lower probability of using formal child care, indicating that these households may be using parents as substitutes for formal child care. Those women receiving family transfers tend to use significantly more formal child care and to work less, which may indicate that such transfers are provided to help subsidize child care use.

\footnotetext{
${ }^{10}$ Results are available on request from the authors.
} 
The presence of children 4-5 years of age increases the probability of using formal child care (increasing the probability of being accepted in the public child care as well as reducing several costs associated to the use of formal child care like transportation costs and other after school arrangements). At the same time, the presence of children younger that 13 years have a negative impact on mother's employment because they still need maternal care. Concerning the regional variables, the availability of part time jobs does not have a significant impact on both decisions. As expected, the condition of the local labor market proxied by the regional unemployment rate negatively influences women's labor participation: in areas where the rate of unemployment is higher, women are less likely to work. At the same time the use of formal child care is discouraged by higher unemployment rate, likely because areas where there is lack of labor market opportunities are also characterized by lack of services like child care. ${ }^{11}$

Finally, the coefficient of correlation between the errors of the two equations is positive and strongly significant, thus indicating the simultaneity in the choices of female participation and use of market child care; demographic and household characteristics, rather than child care characteristics, mainly seem to affect child care decisions.

In Table 6 we reestimate the model after including an interaction term between regional child care cost and residence in the "high child care provision" areas (Emilia Romagna, Lombardia and Veneto). A likelihood ratio test indicates that this model is preferred with respect to the one without this interaction term.

Most of the coefficient estimates are relatively similar across the two specifications with a few notable exceptions. The child care cost variable interacted with residence in the three region area has an associated coefficient on the probability of using formal child care that is negative and significant, whereas the "main effect" of child care costs continues to be insignificantly different from zero. This is consistent with our argument that the price matters only when rationing is not severe. Moreover, the "main effect" of living in the high availability region now becomes signficantly different from zero in both equations, showing that a higher availability of child care increases both

\footnotetext{
${ }^{11}$ We have also used in the estimation the percentage of women employed in the public sector in each region as an indicator of the probability of being employed in the public sector. However, it turns out to be not significant and the results do not change if this variable is excluded from the estimation.
} 
the probability of working and using child care. This could indicate that the main reason why people living in these three regions have higher participation rates and utilization rates of child care is because supply is greater, a conclusion quite consistent with competitive market models. Compared to results from studies from the US, Canada or the UK, which report participation elasticities from -0.02 (Ribar 1995) to -0.8 (Averett et.al. 1997), the price of child care elasticities of our study are located at the lower end of the range. The relatively smaller elasticities might essentially reflect the fact that, since child care facilities are more subsidized in Italy (as in Germany) relatively to the UK. For instance, while in Germany the average hourly child care expenses by child (in Euro) is about 0.76 euro, for Italy parents pay about 1.45 euro per hour, while in the UK the average fees are about 0.96 pounds per hour. ${ }^{12}$ Another explanation has to do with the limitation of hours in child care as well as with the low availability of part time.

Finally, we run a policy experiment similar to Viitanen (2004) for the UK and Wrohlich (2004) for Germany. Using our estimates, we simulate the change in female employment when child care costs are partially or fully subsidized. Viitanen (2004) reports an increase in the labor force participation by 25.4 percentage points in case of a 100 percent subsidy of private child care costs. Running a policy simulation of a hundred percent subsidy to child care costs for Germany Wrohlich (2004) finds an increase in the participation rate of mothers with preschool children of about 3.0 percentage points in the west and about 1.5 in the east (starting from a labor force participation of $63 \%$ in east and $43 \%$ in west Germany). In our case, the same simulation exercise run for the sample of women who are not rationed in the child care market, i.e. those affected by the change in child care costs, leads to an increase in the participation rate of about 13 percentage points (see Table 7 ). If the child care costs are subsidized only by $50 \%$, the change in participation would be of about $7 \%$. Our result lies in between the two studies related to Germany and the UK and is in line with what found by Connelly (1992) who predicts for the US that if child care costs were subsidized 50\%, 64\% of married women with young children would be employed (from the baseline 58.8 ) and if there were universal no-cost child care available $68.7 \%$ of women

\footnotetext{
${ }^{12}$ Notice that the hourly child care costs for Germany and the UK refer to children below 5 years of age, while for Italy refer to children under three years. Since we know that costs are higher for younger children, we expect that child care costs are even higher the UK and Germany if only children below 3 are considered.
} 
would be employed.

\section{Conclusion}

In this paper we analyse the effect of child care system characteristics on women's labour supply decisions. The availability of affordable child care has been identified by policy makers and social scientists in most countries as one of the most important preconditions for high levels of married female participation in the labor market.

The characteristics of the Italian child care system are peculiar. While the quality of public child care is quite high in general, and fairly homogeneous across regions, availability is both limited and heterogenous (with respect to household characteristics such as income and area of residence). Child care, although partially subsidized, lacks both local availability and flexibility in the hours of service. Therefore it is hardly compatible with the full time employment opportunities supplied in the Italian labor market. Child care costs are subsidized to a different extent depending on the municipality. To analyze the effect of child care on mothers' labor market participation decisions in the Italian context we need to take into account the effect of rationing of services.

Our results indicate that labor force participation of women with children is affected by formal child care availability as well as the availability of informal child care. The availability of family support, both in the form of transfers and in the form of presence of parents respectively decreases and increases the probability of market work of mothers. Child care costs are significant only in areas where child care is not severely rationed.

The empirical results seem to indicate that only policies which would reduce the financial burden on the Italian family and provide an expansion of the child care system could have a large positive impact on the labour market participation rate of mothers with young children. 
Table 1 Effect of child care costs on mothers' labor supply

Author

Connelly 1992

Ribar 1995

Viitanen 2004

Powell 1997

Gustafsson and Stafford 1992

Del Boca 1993

Wroolich 2004

Kornstad and Thoresen 2004
Country Coefficient

US negative and significant

US negative and significant

UK negative and significant

Canada negative and significant

Sweden

significant only in areas not rationed

Italy significant only on part time

Germany greater in West Germany

greater in non rationed areas 
Table 2

Simulated Probabilities with and without Rationing

Choice No Rationing Rationing

$\begin{array}{lll}(1,1) & .454 & .191 \\ (1,0) & .073 & .095 \\ (0,1) & .183 & .216 \\ (0.0) & .289 & .499\end{array}$


Table 3

Descriptive Statistics

Means and (Standard Deviations)

\begin{tabular}{lc}
\hline \hline Variables & \\
\hline Participation & $(49.7)$ \\
& 32.2 \\
Age of the Wife & $(4.74)$ \\
& 35.68 \\
Age of the Husband & $(5.34)$ \\
& 10.91 \\
Wife Schooling & $(3.47)$ \\
& 10.71 \\
Husband Schooling & $(3.73)$ \\
& 8.74 \\
Family non Labor Income & $(2.69)$ \\
(in thousands Euro) & 14.41 \\
Husband Labor Income & $(4.24)$ \\
& 0.11 \\
Family Transfers & $(0.31)$ \\
& 0.90 \\
Parents Alive & $(0.30)$ \\
& 0.14 \\
Children aged 4-5 & $(0.35)$ \\
& 0.44 \\
Children aged 6-13 & $(0.65)$ \\
& 1.45 \\
Hourly Child Care Costs & $(2.03)$ \\
(only those who pay) & 8.31 \\
Part Time & $(1.71)$ \\
& 23.22 \\
Women in the PA & $(7.40)$ \\
& 12.47 \\
Unemployment rate & $(8.29)$ \\
& \\
\hline \hline
\end{tabular}


Table 4

Proportion of work and child care use in areas with more or less rationing

$\begin{array}{ccc} & N W=1 & N W=0 \\ \text { work and child care } & .158 & .117 \\ \text { work, no child care } & .458 & .290 \\ \text { no work, use child care } & .074 & .083 \\ \text { no work, no child care } & .310 & .509 \\ \text { Child care availability } & 15 \% & 3.5 \% \\ \text { Children in waiting list } & 31.3 & 34.5\end{array}$


Table 5 Participation and Child Care Decision

\begin{tabular}{|c|c|c|c|c|}
\hline Variables & Participation & Marg. effects & Child care & Marg. effects \\
\hline Hourly Child Care Costs & $\begin{array}{c}.418 \\
(.269)\end{array}$ & .163 & $\begin{array}{l}-.218 \\
(.285)\end{array}$ & -.014 \\
\hline NW & $\begin{array}{c}.145 \\
(.129)\end{array}$ & .057 & $\begin{array}{c}.097 \\
(.130)\end{array}$ & .028 \\
\hline Age of wife & $\begin{array}{c}.087^{* *} \\
.020\end{array}$ & .034 & $\begin{array}{c}.021 \\
(.021)\end{array}$ & .006 \\
\hline Education of wife & $\begin{array}{l}.108^{* *} \\
(.018)\end{array}$ & .042 & $\begin{array}{c}.027 \\
(.019)\end{array}$ & .007 \\
\hline Education of husband & $\begin{array}{c}-.031 \sim \\
(.018)\end{array}$ & -.012 & $\begin{array}{l}.036 \sim \\
(.019)\end{array}$ & .010 \\
\hline Age of husband & $\begin{array}{c}-.021^{*} \\
(.011)\end{array}$ & -.008 & $\begin{array}{c}.002 \\
(.011)\end{array}$ & .001 \\
\hline Non labor Income & $\begin{array}{l}-.005 \\
(.027)\end{array}$ & -.002 & $\begin{array}{c}.038 \\
(.029)\end{array}$ & .010 \\
\hline Husband labour income & $\begin{array}{c}.009 \\
(.011)\end{array}$ & .003 & $\begin{array}{c}.003 \\
(.011)\end{array}$ & .001 \\
\hline Family Transfers & $\begin{array}{l}-.389^{*} \\
(.200)\end{array}$ & -.145 & $\begin{array}{l}.533^{* *} \\
(.206)\end{array}$ & .167 \\
\hline Parents Alive & $\begin{array}{l}.584^{* *} \\
(.182)\end{array}$ & .211 & $\begin{array}{c}-.309 \sim \\
(.176)\end{array}$ & -.090 \\
\hline Children aged 4-5 & $\begin{array}{c}-.208 \sim \\
(.119)\end{array}$ & -.082 & $\begin{array}{l}.312^{*} \\
(.124)\end{array}$ & .085 \\
\hline Children aged 6-13 & $\begin{array}{c}-.120 \sim \\
(.077)\end{array}$ & -.047 & $\begin{array}{c}.086 \\
(.065)\end{array}$ & .024 \\
\hline part time & $\begin{array}{l}.018 \\
(.030)\end{array}$ & .007 & $\begin{array}{l}-.015 \\
(.033)\end{array}$ & -.004 \\
\hline unemployment rate & $\begin{array}{c}-.024^{* *} \\
(.009)\end{array}$ & -.009 & $\begin{array}{l}-.019^{*} \\
(.009)\end{array}$ & -.006 \\
\hline Constant & $\begin{array}{c}-4.11^{* *} \\
(.622) \\
\end{array}$ & & $\begin{array}{c}-1.78^{* *} \\
(.678) \\
\end{array}$ & \\
\hline $\mathrm{N}$ cases & \multicolumn{4}{|c|}{1267} \\
\hline log likelihood & \multicolumn{4}{|c|}{$-1320.664 .78$} \\
\hline Correlation coefficient $(\rho)$ & \multicolumn{4}{|c|}{$0.244^{* *}(0.053)$} \\
\hline
\end{tabular}


Table 6 Participation and Child Care Decision

\begin{tabular}{|c|c|c|c|c|}
\hline Variables & Participation & Marg. effects & Child care & Marg. effects \\
\hline Hourly child care costs predicted & $\begin{array}{l}.459 \sim \\
(.277)\end{array}$ & .180 & $\begin{array}{l}-.192 \\
(.287)\end{array}$ & -.052 \\
\hline NW & $\begin{array}{c}1.223^{* *} \\
(.435)\end{array}$ & .450 & $\begin{array}{l}.877 * \\
(.427)\end{array}$ & .291 \\
\hline Hourly child care costs*NW & $\begin{array}{l}-.564^{* *} \\
(.217)\end{array}$ & -.221 & $\begin{array}{r}-.408 * \\
(.212)\end{array}$ & -.111 \\
\hline Age of wife & $\begin{array}{l}.083^{* *} \\
(.022)\end{array}$ & .033 & $\begin{array}{c}.018 \\
(.021)\end{array}$ & .005 \\
\hline Education of wife & $\begin{array}{l}.113^{* *} \\
(.018)\end{array}$ & .044 & $\begin{array}{l}.030 \sim \\
(.018)\end{array}$ & .008 \\
\hline Education of husband & $\begin{array}{l}-.028 \\
(.018)\end{array}$ & -.011 & $\begin{array}{l}.038 * \\
(.018)\end{array}$ & .010 \\
\hline Age of husband & $\begin{array}{c}-.020 \sim \\
(.011)\end{array}$ & -.008 & $\begin{array}{c}.002 \\
(.011)\end{array}$ & .001 \\
\hline Non labor Income & $\begin{array}{c}.002 \\
(.027)\end{array}$ & .001 & $\begin{array}{c}.042 \\
(.029)\end{array}$ & .012 \\
\hline Husband labor income & $\begin{array}{c}.009 \\
(.011)\end{array}$ & .003 & $\begin{array}{c}.003 \\
(.011)\end{array}$ & .001 \\
\hline Transfers & $\begin{array}{l}-.390 * \\
(.196)\end{array}$ & -.146 & $\begin{array}{l}.536^{* *} \\
(.210)\end{array}$ & .171 \\
\hline Parents Alive & $\begin{array}{l}.546^{* *} \\
(.185)\end{array}$ & .198 & $\begin{array}{c}-.334 \sim \\
(.187)\end{array}$ & -.101 \\
\hline Children aged 4-5 & $\begin{array}{l}-.206 \sim \\
(.117)\end{array}$ & -.081 & $\begin{array}{l}.313^{*} \\
(.126)\end{array}$ & .086 \\
\hline Children aged 6-13 & $\begin{array}{c}-.115 \sim \\
(.083)\end{array}$ & -.045 & $\begin{array}{c}.092 \\
(.074)\end{array}$ & .025 \\
\hline part time & $\begin{array}{l}.014 \\
(.031)\end{array}$ & .006 & $\begin{array}{l}-.018 \\
(.033)\end{array}$ & -.005 \\
\hline unemployment rate & $\begin{array}{c}-.023^{* *} \\
(.008) \\
\end{array}$ & -.009 & $\begin{array}{r}-.018^{*} \\
(.009) \\
\end{array}$ & -.005 \\
\hline $\mathrm{N}$ cases & \multicolumn{4}{|c|}{1267} \\
\hline loglikelihood & \multicolumn{4}{|c|}{-1315.791} \\
\hline Correlation coefficient $(\rho)$ & & $0.237^{* *}$ & $(0.053)$ & \\
\hline
\end{tabular}


Table 7

Labor supply simulations

\begin{tabular}{lcccc}
\hline \hline & Country & Baseline & $50 \%$ subsidy & $100 \%$ subsidy \\
\hline Our study & Italy & 61 & $+6.9 \%$ & $+13.2 \%$ \\
Viitanen (2004) & UK & 50.7 & +13.8 & $+25 \%$ \\
Wrohlich (2004) & Germany & $43 \%$ west, $63 \%$ in east & - & $+3 \%$ (west), $1.5 \%$ (east) \\
Connelly (1992) & US & 58.8 & $+5.2 \%$ & +9.9 \\
\hline \hline
\end{tabular}




\subsection{Appendix 1- Statistical matching}

The purpose of this section is to explain how the statistical matching was performed.

First, we select married couples with both partners present. Next, we take into consideration only women who are housewives, unemployed, students or employed; in addition, they have to be married to men who are either unemployed, retired or employed. ${ }^{13}$ This reduces the sample to 3140 couples belonging to the SHIW survey and to 8347 from the Multiscopo survey. In order to impute non labor household income, the total sample of 11487 households is used. When the labor earnings and hours of work from women and men of the SHIW survey to women of the Multiscopo survey have to be imputed, the statistical matching is realized respectively only on women who work (1122 from the SHIW and 3039 from the Multiscopo) and on men who work (2003 from the SHIW and 5669 from the Multiscopo) to further reduce imprecision.

As a baseline analysis, we compare the averages for all of variables the two surveys have in common. We compute descriptive statistics for women and for men related to selected variables from the two surveys (members, number of children in different age groups, age, education, area of residence). ${ }^{14}$

The next step would be to match units from the two surveys, conditional on the common variables X. However, when the vector of common variables is large, this procedure is rather complicate. Rosenbaum and Rubin (1983) suggest that matching can be performed on the propensity score, which is the conditional probability of belonging to a sample, e.g. the Multiscopo sample. In order to compute the propensity score, we have run a probit regression of the binary indicator taking value 1 for observations in the Multiscopo sample (and 0 for the SHIW sample) over the set of above-mentioned common household characteristics plus some interaction terms. ${ }^{15}$ Since the propensity score is a continuous variable, exact matches will rarely be achieved and a

\footnotetext{
${ }^{13}$ We exclude self-employed workers in order to have a more uniform sample for the matching procedure, and retired women because they are not relevant to the problem at hand (child care opportunities for very young children).

${ }^{14}$ Descriptive statistics and comparisons are available on request from the authors.

${ }^{15}$ The choice of interaction or higher order term to include for estimating the propensity score is determined solely by the need to obtain an estimate of the propensity score that satisfies the balancing property (see Dehejia and Wahba, 1999). To build the propensity score we follow the algorithm proposed by Dehejia and Wahba (1998).
} 
certain distance between individuals belonging to the two samples has to be allowed. Thus, we choose to use the radius method of matching; among the units within the radius, we randomly select one unit, and we repeat this procedure 20 times. The final value of each imputed variables is obtained by averaging the 20 values previously obtained. ${ }^{16}$ After the statistical matching is performed, each individual from the Multiscopo will be imputed the annual labor earnings, the annual hours of work and the household non labor income of a similar individual from the SHIW according to the value of the function of the propensity score.

Finally, we proceed with an internal evaluation of the statistical matching in two steps. First, we compare the average values between the values of the imputed variables after the matching and the corresponding average values in the donor set, i.e. the SHIW sample; then we evaluate the preservation of relations between variables. The results are quite satisfactory since the imputed variables are not statistically different from the original ones in almost all the cases and the differences between the common-fusion correlations in the SHIW data set versus the fused Multiscopo data set seem to be well preserved for most variables (see Del Boca, Locatelli and Vuri 2005 for details).

\footnotetext{
${ }^{16}$ The standard errors are computed by bootstrapping.
} 


\subsection{Appendix 2-}

Table A.1

Child care availability, waiting list and Part time by Region

\begin{tabular}{lccc}
\hline \hline Regions & CC-regional & Children in the & Part Time \\
\hline & distribution & waiting list & \\
\hline Piemonte/Valle d'Aosta & 8.7 & 38.9 & 7.65 \\
Lombardia & 17.3 & 31.4 & 8.97 \\
Trentino & 2.4 & 27.0 & 12.31 \\
Friuli & 2.3 & 39.8 & 11.19 \\
Veneto & 17.1 & 41.7 & 9.77 \\
Liguria & 2.8 & 56.7 & 7.87 \\
Emilia & 10.6 & 20.8 & 10.79 \\
Toscana & 6.4 & 35.7 & 9.21 \\
Umbria & 1.85 & 29.8 & 8.56 \\
Marche & 4.8 & 33.1 & 8.62 \\
Lazio & 7.95 & 37.5 & 7.47 \\
Abruzzo-Molise & 1.05 & 29.5 & 5.44 \\
Campania & 5.45 & 40.7 & 6.30 \\
Puglia & 2.9 & 29.0 & 6.37 \\
Basilicata & 0.9 & 27.2 & 6.42 \\
Calabria & 1.95 & 27.6 & 8.88 \\
Sicilia & 3.6 & 29.6 & 9.01 \\
Sardegna & 1.9 & 36.0 & 9.03 \\
\hline Soures $:$ SST & A & & \\
\hline
\end{tabular}

Sources : IST AT : Annuario Statistico Italiano1999-2001;

Ministero del Lavoro e delle Politiche Sociali : I servizi educativi per la prima infanzia, 2002

$*$ In the public sector

** Authors' calculations from the Labor Force Survey 1998 


\section{References}

[1] Addabbo T (2001), "Labour Supply and child care in Emilia Romagna", AIEL 2001 mimeo Florence.

[2] Antonnen Sipilla (1996), "European Social care Service: Is it possible to identify models?", Journal of European Social Policy

[3] Averett S.L., Peters H.E., Waldman D. (1997), "Tax credits labor supply and child care", The Review of Economics and Statistics 79 (1)1, pp.125135

[4] Becker, G., (1981). A Treatise on the Family, Harvard University Press.

[5] Blau, D. M., (1991). The Economics of Child Care, Russel Sage New York.

[6] Blau, D.M. and Robins P.K. (1988), "Child Care Costs and Family Labor Supply", The Review of Economics and Statistics 70 (3), pp. 37438

[7] Boeri T., Del Boca D., Pissarides C. (2005), Women at work: an economic perspective, Oxford University Press.

[8] Bradshaw, J., Ditch, J., Holmes, H., Whiteford, P. (1997). Support for the Children: A Comparison of Arrangements for fifteen Countries, London: Department of Social Security.

[9] Chevalier, A. and Viitanen T.K. (2002), "The Causality between Female Labour Supply and the Availability of Child Care", Applied Economics Letters 9, 915-918.

[10] Chiuri, M.C. (2000) "Quality and Demand of Child Care and Female Labour Supply in Italy", Labour 14, 97-118.

[11] Cigno, A. (1991), Economics of the Family Oxford University Press, Oxford.

[12] Cobb Clark, D., Mitchel, D., Mitchel, A.M., (2000), "Reassessing the Role of Child Care Costs in the Work and Care Decisions of Australian Families", The Australian Bulletin of Labour, 26 (4), pp. 197-215. 
[13] Connelly, R. (1992). "The Effect of Child Care Costs on Married Women's Labor Force Participation", Review of Economics and Statistics 74 (1), 83-90.

[14] Dehejia, R., and Wahba, S. (1998), "Propensity Score Matching Methods for Non-Experimental Causal Studies", NBER, Working Paper n. 6829

[15] Dehejia, R, and Wahba, S. (1999), "Causal Effects in Non-experimental Studies: Reevaluating the Evaluation of Training Programs", JASA: 1053-1062

[16] Del Boca D., Locatelli M. and Vuri D. (2005) "Child care Choices of Italian Households", Review of Economics of the Household 3, 4.

[17] Del Boca D. (2002) "The Effects of Child care and Part time on the Participation and Fertility Decisions of Married Women", Journal of Population Economics, 14.

[18] Del Boca, D. (1993), Offerte di Lavoro e Politiche Pubbliche, Nuova Italia Scientifica, Roma.

[19] Ermisch, J. F. (1989) "Purchased Child Care, Optimal Family Size and Mother's Employment: theory and Econometric Analysis", Journal of Population Economics 2, 79-102.

[20] Esping-Andersen G. (1999), Social Foundation in Post industrial Economies, Oxford Oxford University Press

[21] Ferrera, M. (1996), "The Southern Model in Social Europe", Journal of European Social Policy 6 (1), 17-37.

[22] Fondazione degli Innocenti (2002), "I servizi educativi per la prima Infanzia", Quaderno 21.

[23] Gornick, J.C., Meyers, M.K., Ross, K. E. (1997), "Supporting the Employment of Mothers: Policy Variation across Fourteen Welfare states", Journal of European Social Policy, (7) 45-70.

[24] Gustafsson and Stafford (1992), "Child care subsidies and Labor supply in Sweden", Journal of Human Resources 2, pp 204-29. 
[25] Heckman J. (1974), " The Effect of child care programs on women work effort", Journal of Political Economy 82, 2 pp 136-63.

[26] Heckman J.J. (1993) "What has been learned about labor supply in the past twenty years", American Economic Review Papers and Proceedings vol 83 n.2 116-121

[27] ISTAT (1995a), " Rilevazione delle forze di lavoro - medie 1993" Collana L'Informazione, no.17.

[28] _-_-_ (1995b), " Statistiche della Previdenza, della Sanità e dell'Assistenza Sociale" anni 1992, 1993, annuario no.3.

[29] _-___-_ (1995c), " Statistiche della Scuola Materna ed Elementare" anno scolastico 1992-93, annuario no.4.

[30] _-_-_ (1995d), "Popolazione e Movimento Anagrafico dei Comuni" anno 1993, annuario no.6.

[31] -(1999-2000), Annuario Statistico Italiano.

[32] Kimmel , J. (1998), "Child care Costs as a barrier to Employment for Single and Married Mothers", The Review of Economics and Statistics 287-299

[33] Kornstad, T. and Thoresen T.O. (2003), "A Discrete Choice Model for Labor Supply and Child Care", Statistics Norway mimeo.

[34] Kreyenfeld, M. and Hank K. (2000),: "The Availability of Child Care and Mothers' Employment in West Germany", DIW Discussion Paper No. 191, Berlin.

[35] OECD 2001, Employment Outlook

[36] Powell L. (1997), "The Impact of Child care costs on Labour Supply of Married Mothers: Evidence from Canada",. Canadian Journal of Economics 30 (3) :577-594

[37] Ribar, D. (1992), "Child Care and the Labour Supply of Married Women: Reduced Form Evidence", Journal of Human Resources, 27 (1): $135-165$. 
[38] Ribar D. (1995), " A structural Model of Child Care and the Labour Supply of Married Women", Journal of Labour Economics 3(13)

[39] Wrohlich, K. (2004), "Child Care Costs and Mothers' Labor Supply: An Empirical Analysis for Germany", DIW Discussion Papers 412, German Institute for Economic Research.

[40] Viitanen, T. (2004), "Costs of Child Care and Female Employment in England", Mimeo. 